\title{
Substantive and Procedural Rules in International Adjudication: Exploring their Interaction in Intervention before the International Court of Justice
}

\section{Matina Papadaki}

\section{Introduction}

In this chapter we will follow the thread of the separation of substantive and procedural rules in international adjudication and its importance in international law, using as our example intervention before the International Court of Justice (ICJ).

As succinctly put by Judge Weeramantry "intervention affords an example par excellence of the celebrated observation that substantive law is often secreted in the interstices of procedure. The subject is therefore one of special importance, not merely in the sphere of procedure but in the sphere of substantive law as well."1

We begin our analysis by briefly sketching the origins of this separation, to demonstrate its importance, while noting that boundaries are not only blurred but also permeable. We then turn to examining the history and practice of intervention before the ICJ. More specifically, a typology of interactions shows how procedure can uphold and reflect the values carried by substantive rules and how substantive rules can in turn shape the interpretation of procedural rules.

Our goal is to draw an impressionistic picture of the role of intervention through a different and largely under-explored angle of the interaction between substance and procedure.

* Research Fellow at the Max Planck Institute Luxembourg for Procedural Law.

1 Sovereignty over Pulau Ligitan and Pulau Sipadan (Indonesia/Malaysia), Application for Permission to Intervene, Judgment, ICJ Reports 2001, 575, Separate Opinion of Judge Weeramantry, para. 12, emphasis added. 


\section{Distinguishing Substantive and Procedural Rules in International Adjudication}

Our analysis will assume a clear-cut distinction between the two sets of rules of procedure on the one hand and of substance on the other so as to pinpoint their interactions. Consequently, in this chapter procedural rules will refer to the rules and principles regulating the conduct of proceedings of the ICJ and the rights of the States stemming from these, while substantive rules will refer to rights and obligations that exist irrespective of the procedure of adjudication in the ICJ.

However, prior to analysing intervention before the ICJ we consider it important to highlight some aspects of the fluidity of this distinction. As per most theoretical distinctions, the relationship between the two components of the binaries is often challenged in theory and practice and is mostly considered as a spectrum with a permeable boundary. This is certainly the case of the differentiation between substantive and procedural rules in international adjudication.

What is more, the history of codifying international rules of adjudicative procedure is short. A very rough sketch would go back to $19^{\text {th }}$ century arbitration and the codification efforts of the Institut de Droit International, Project for the Regulation of the International Arbitral Procedure (1875 IDI Project), ${ }^{2}$ as well as the Hague Conventions for the Pacific Settlement of International Disputes. ${ }^{3}$ The International Court of Justice, inspired by the 1907 Convention, slowly progresses to develop its own autonomous procedure and in turn influence other international jurisdictions ${ }^{4}$ while more recently it has been argued that we can talk of a "common law of international adjudication".5 Thus, previously valid exhortations that interna-

2 Projet de règlement pour la procédure arbitrale internationale, 1 Annuaire de l'Institut de Droit International (1877), 126.

3 Convention for the Pacific Settlement of International Disputes, 29 July 1899,187 CTS 410; Convention for the Pacific Settlement of International Disputes, 18 October 1907, 205 CTS 233.

4 S. Rosenne, The Law and Practice of the International Court of Justice 1920-2005, $4^{\text {th }}$ ed. (2006) vol. III, 1021-1022 [Rosenne, The Law and Practice], who argues that international procedural law in the International Court of Justice drew from the $19^{\text {th }}$ century arbitral practice, which in turn used analogies stemming from domestic procedures.

5 C. Brown, A Common Law of International Adjudication (2007), where the proliferation of international courts and tribunals prompted the author to comparatively examine the procedure and remedies of a wide variety of international judicial fo- 
tional procedural law is the "Antarctica of international law", and that most international law scholars prefer to deal with the decisions and not the procedural "anfractuosities of the route", 7 are no longer true, as proven by the monographs on the issue, ${ }^{8}$ and the growing interest in this field. ${ }^{9}$ However, many angles of the topic remain under-explored.

Despite this recent increase in interest, a clear distinction between substantive and procedural rules remains elusive and has been diachronically difficult. Indeed, Shabtai Rosenne noted that "a procedural incident which in the conception of internal legal systems is likely to be regarded as procedural, will appear in international law indifferently as one of substance or of procedure" and since, in contrast to the domestic legal systems, judicial dispute settlement is volitional, procedural norms "are indistinguishable, in their creation as in their effect, from those substantive norms through the application of which that dispute will be settled". 10

ra, leading him to the conclusion that their convergences give rise to a common law of adjudication.

6 A. H. Feller, The Mexican Claims Commissions: 1923-34 (1935), vii.

7 H. W. A Thirlway, Procedural law and the International Court of Justice, in V. Lowe and M. Fitzmaurice (eds.), Fifty Years of the International Court of Justice: Essays in honour of Sir Robert Jennings (1996), 389.

8 For general works on international procedure, see for example, inter alia, J. Ralston, The law and procedure of international tribunals: being a résumé of the views of arbitrators upon questions arising under the law of nations and of the procedure and practice of international courts (1926); J.C. Witenberg, L'Organisation Judiciaire: La Procédure et la Sentence Internationales (1937); M. Hudson, Manley Hudson, International Tribunals: Past and Future (1944); M. Bos, Les conditions du procès en droit international public (1957); V. S. Mani, International Adjudication: Procedural Aspects (1980); Brown, supra note 5; G. Biehler, Procedures in International Law, (2008); E. Lauterpacht, Principles of Procedure in International Litigation, 345 Collected Courses of the Hague Academy of International Law (2011); C. T. Kotuby and L. A. Sobota, General Principles of Law and International Due Process: Principles and Norms Applicable in Transnational Disputes (2017).

9 The so called "proliferation" of international courts and tribunals generally boosted academic interest in many aspects of international adjudication. It is also noteworthy that the present volume and the very launch of the Department of International Law and Dispute Resolution within the Max Planck Institute Luxembourg which is dedicated to the study of International and European procedural law further attests to emergence of this interest.

10 Rosenne, The Law and Practice, supra note 4, 1024. 
In our view however, even if the creation of substantive and procedural rules could be considered indistinguishable, ${ }^{11}$ the difference as to their effects can be extremely important.

The local remedies rule offers a good example challenging the absolute character of the distinction while showing the important implications of the categorization. The local remedies rule can either be considered as a substantive prerequisite of 'perfecting' an internationally wrongful act, or as a procedural bar to international adjudication. In the first situation there will be no internationally wrongful act until local remedies are exhausted, while in the second, where it is classified as procedural, exhaustion will be a matter of admissibility of the claim.

There is however a third situation which makes the distinction more nuanced: the nature of the exhaustion of local remedies will be dependent on the rule breached. If the injury to the alien stems from a breach of domestic law, then the internationally wrongful act will arise out of the act or omission constituting denial of justice, in which case the local remedies rule will be substantive. Where the injury instead stems from a breach of international law, international responsibility arises at the moment of the breach and exhaustion of local remedies is procedural in nature, a precondition to bringing the claim before an international court. However, if the rule breached is solely of international law with no counterpart in domestic law, there cannot be a requirement of exhaustion of local remedies. ${ }^{12}$

11 Even this aspect can be considered contentious since substantive rules are created by States but international adjudicative procedural rules are largely created by the international courts themselves, which are generally masters of their own procedure. This is often explicitly provided for in their Statutes (see for example Article 30 of the ICJ Statute, Article 16 of the ITLOS Statute and Article 17(9) of the WTO Dispute Settlement Understanding) which tend to draw from the practice of other tribunals rather than of States to establish customary procedural law. Consequently, doubts have been expressed as to whether sources of international law accurately reflect the sources of international procedural law. As H. Thirlway has noted "[i]t may be supposed that in principle the enumeration in article 38 of the ICJ Statute is broadly valid for international procedural law as part of international law; but is that sufficient?", supra note 7,389 (emphasis added); for a recent summary of the debate, see C. Brown, Inherent Powers in International Adjudication, in C. Romano et al. (eds.), Oxford Handbook of International Adjudication (2014), 829, 830-832. The reason however that we maintain that the creation of such rules could still be considered indistinguishable is that court rules are derivatively and secondarily a product of State consent, since the very norms referred to above are laid down by States.

12 See International Law Commission, "Second Report on Diplomatic Protection by Mr. J. Dugard, Special Rapporteur”, UN Doc. A/CN.4/514, 28 February 2001, 
This distinction also becomes readily apparent in cases regarding State immunity and violation of jus cogens rules. In such cases, it is the characterisation of the rules on immunity that determines the outcome. If State immunity is not viewed as a procedural bar to jurisdiction this would mean that the rules on immunity could be displaceable by jus cogens norms if deemed in conflict with them. ${ }^{13}$ The stance of the Court has been clear; the rules of activation of its jurisdiction are procedural and do not interact with the rules deciding legal rights on the merits of the case. Literature however is not unanimous on the validity of this view or on the value of the substance procedure divide itself. ${ }^{14}$

While the rules on intervention of third parties in the ICJ are easier to classify as procedural than those of the examples above, the distinction between substantive and procedural rules produces equally outcome-determinative results albeit in a different way. In third party intervention in the ICJ we can trace how the procedural rules embed choices about which inter-

106-114, paras. 32-66, especially para. 33 on the relevance and importance of the distinction; Also J. R. Crawford and T. D. Grant, Local Remedies, Exhaustion of, in R. Wolfrum (ed.), The Max Planck Encyclopedia of Public International Law, (last updated 2007), available at http://opil.ouplaw.com/view/10.1093/law:epil/978 0199231690/law-9780199231690-e59 (last visited 30 October 2018), paras. 35-41.

13 See Arrest Warrant Case (Democratic Republic of the Congo v. Belgium), Judgment, ICJ Reports 2002, 3, 25, para. 60, and Jurisdictional Immunities of the State (Germany v. Italy, Greece intervening), Judgment, ICJ Reports 2012, 99, 124, para. 58.

14 For an overview of the two sides of the debate and focusing on the proceduralsubstantive divide, see S. Talmon, Jus cogens after Germany v. Italy: Substantive and Procedural Rules Distinguished, 25 LJIL (2012), 979, who agrees with the approach of the ICJ and argues that the substance and procedure divide is both wellestablished in international law despite the absence of predetermined criteria and differences with respect to the classification of some rules, noting that the formalistic and technical nature of the distinction is needed for clarity and predictability of law. He adds that criticisms focus on the undesirability of the outcome in this specific case rather than on the logic of the categories of substance and procedure. Cf., A. Orakhelashvili, The Classification of International Legal Rules: A Reply to Stefan Talmon (2013), 26 LJIL 89, who argues that the distinction between substance and procedural is artificial, that there is no cognizable category of procedural rules in international law and it is used to support political and ideological preferences so as to prevent adjudication of certain classes of actors and claims. In our view however, the category of procedural rules and principles in international adjudication exists and its unqualified denial is at least factually inaccurate. The fact that it expresses political and ideological choices is an important aspect which needs to be researched but which does not negate the existence of a distinction between procedural and substantive rules. 
ests are viewed as warranting participation. What is and is not deemed as an admissible request for intervention provides links between the procedural device and the substance of the right vindicated. Consequently, the separation is more nuanced than in cases of norm conflict as in the example of State immunities. It is nonetheless important to note the fluidity of this definition and the importance of categorisation.

Having the above definitions and caveats in mind, we will explore whether providing, on a limited scale, a typology of the substance-procedure interaction brings to light useful linkages.

\section{Points of Entry to the Interaction Between Substance and Procedure}

The fact that the boundary between substance and procedure is hazy and movable, as already demonstrated, makes the effort to capture their interaction inherently challenging.

However, two entry points into the examination of this interaction can be discerned. The first is to start from the substantive end, choosing a substantive right, or a category of substantive rights, and examine how they are obtained through procedures in international adjudication and the relation between substance and procedure. The second is to start from the procedural part, choosing a procedural institution or rule and trying to uncover the substantive rights it seeks to vindicate and on which levels it interacts with them.

The first approach is potentially more 'measurable' and less elusive, in that we look for the end result of the judicial protection of a right or a category of rights, the attainment of substantive rights. On the other hand, the second approach may appear counter-intuitive, in that procedural rules are supposed to be mere vehicles through which substance is carried to its end point. The first approach has received attention in international law in the context of the protection of public goods, or common interests. ${ }^{15}$ This

15 On the emergence of community interest and its expression in international law, see generally B. Simma, From Bilateralism to Community Interest in International Law, 250 Collected Courses of the Hague Academy of International Law (1994), 217; S. Villalpando, The Legal Dimension of the International Community: How Community Interests Are Protected in International Law, 21 EJIL (2010), 387. On the particular issue of interface between substance and procedure with relation to common interests, see M. Benzing, Community Interests in the Procedure of International Courts and Tribunals, 5 The Law \& Practice of Int'l Court and Tribunals (2006), 369; A. Nollkaemper, International Adjudication 
theoretical engagement can be explained from the fact that in international law, substantive rules do not necessarily grow in tandem with procedural law and remedies. ${ }^{16}$ There seems to be an asynchronous development that creates tension between new substantive rights or interests, which transcend bilateralism, and adjudicative procedures, designed to cater for bilateral disputes. ${ }^{17}$ Using this example as an entry to the interplay between substance and procedure in the protection of common interests and public goods, we can trace a clear link between the procedure and remedies. This is so because in order to examine whether protection can be accorded and attained through adjudicative procedures in international law, the issue will necessarily turn to jurisdiction and standing. Though the latter concepts are procedural, they depend on primary norms catering for multilateral or collective interests and their counterpart secondary norms of state responsibility, relating mainly to the conditions of its invocation. ${ }^{18}$ This relation, even briefly examined, can reveal a feedback loop between the evolution of the law and that of procedure.

Conversely, any effort to assess the interrelationship from the procedural end cannot but start from broader, abstract, and goal-oriented underpin-

of Global Public Goods: The Intersection of Substance and Procedure, 23 EJIL (2012), 269; W. Wolfrum, Interventions in Proceedings before International Courts and Tribunals: to what Extent may Interventions serve the Pursuance of the Community Interests, in N. Boschiero et al. (eds.), International Courts and the Development of International Law: Essays in Honour of Tullio Treves (2013), 219.

16 E. Cannizzaro and B. Bonafé, Of Rights and Remedies: Sovereign Immunity and Fundamental Human Rights, in Ulrich Fastenreth et al. (eds.), From Bilateralism to Community Interest: Essays in Honour of Bruno Simma (2011), 825, arguing that the development of primary rules in the field of human rights is growing faster than and with not corresponding norms of secondary rules of responsibility and especially remedies. See also Benzing, supra note 15, 372-373, and Nollkaemper, supra note $15,770-771$, noting the tension between structurally bilateralist procedures and remedies.

17 Emphasizing the bilateral nature of disputes in the ICJ through an a contrario argument, see L. Fisler Damrosch, Multilateral Disputes in The International Court of Justice, in L. Fisler Damrosch (ed.), The International Court of Justice at a Crossroads (1987), 376.

18 Following the thread of the evolution of the concept of collective legal interests in the law of treaties and its implication for the law of state responsibility in terms of standing, see J. R. Crawford, Multilateral Rights and Obligations in International Law, 319 Collected Courses of the Hague Academy of International Law (2006), 421-451. 
nings. ${ }^{19}$ In this vein, we will start from the premise that the procedural law of any court or tribunal is created and developed with the view to carry out the functions entrusted to it. But it also follows from the above that any observation of the interaction is very context-sensitive, that is, related to the examined tribunal, and content-dependent, related to the procedural rule under examination. For this reason, it would be easier and perhaps more instructive to not examine connections in abstracto, especially in the international plane where the goals of the Court are very different. Thus, by way of experiment to trace this interrelationship from a different angle, we will try to use as an entry point the institution of intervention in contentious proceedings of the ICJ.

The choice of the ICJ is for two main reasons. ${ }^{20}$ First, it is the oldest existing permanent international court, and as the successor of the Permanent Court of International Justice, its procedure ${ }^{21}$ is a prototype of international adjudicatory procedure while also providing a link to the earliest efforts of regulating international dispute settlement. Second, it is "the only international court of a universal character with general jurisdiction",22 making it ideal for testing a variety of substantive issues.

The choice of the procedural 'device' of intervention is made because it challenges the structural underpinnings of this court and the primarily bilateral structure of ICJ litigation. ${ }^{23}$ The Court has a delicate balance to keep. On the one hand, it cannot unduly emphasise bilateralism. This would be a necessary implication if the Court were overtly reluctant to al-

19 The approach to assess procedural 'devices' and rules via the spectrum of attainment of the Court's goals and mandate draws from the logic but not the specific parameters of: Y. Shany, Assessing the Effectiveness of International Courts (2014).

20 It has to be noted that the two criteria are expressed as objective characteristics of the ICJ rather than as axiologically important.

21 An Informal Inter-Allied Committee (1943-1944), the mandate of which was to examine "the Future of the PCIJ", posited that: "little change is required in the procedure of the Court, which has worked satisfactorily in practice", United $\mathrm{Na}$ tion: Report of the Informal Inter-Allied Committee on the Future of the Permanent Court of International Justice, 39(1) Supp. AJIL (1945), 1, 24, para 77.

22 UNGA, Report of the International Court of Justice for 1 August 2014 until 31 July 2015, UN Doc. A/70/4, 12 November 2015, 12 para. 40.

23 Highlighting the essentially bilateral architecture of the procedures of the Court, see T. D. Gill, Litigation strategy at the International Court: a case study of the Nicaragua v. United States dispute (1989), 91, arguing that such bilateralism is 'understandable' given the tradition and history of interstate arbitration which is tied to the formation of the rules of procedure and that litigation strategy is complex enough in the bilateral disputes and thus occurrences of multiparty disputes will remain low. 
low intervention, thus signaling reticence to hear third party rights or interests. Arguably, this would go against its broader role as the "principal judicial organ of the United Nations" ${ }^{24}$ which in turn implies supporting the purposes of the UN in the administration of international justice and the pacific settlement of disputes. On the other hand, it has to safeguard party autonomy so as not to deter States from bringing their disputes to the Court. ${ }^{25}$

\section{Examples of Modes of Interaction}

Having set the general context and angle, we will try to provide a framework of interaction between substance and procedure in intervention before the ICJ.

First, it has to be noted that the narrative chosen in this paper does not focus on the classical perplexities surrounding intervention. The intricacies and importance of many issues are intertwined with this procedural device. This could result in a misrepresentation of a complex image. As a result, the exercise might appear as a very neat picture to those uninitiated in the technicalities of intervention in the ICJ, and in contrast, a very minimalist approach to those that have studied it. Thus, we feel obliged to signal these complexities. ${ }^{26}$

24 United Nations, Charter of the United Nations, 24 October 1945, 1 UNTS XVI, Article 92.

25 Arguing for the need to keep a balance between these conflicting interests, see C. Chinkin, Third Parties in International Law (1993), 149.

26 As R. Bilder pertinently noted in his book review of the work of S. Rosenne on the subject: "[T]he procedural question of intervention in interstate proceedings before the ICJ encapsulates many larger leitmotifs of public international law. It goes right to the heart of the matter of the nature of the consent of states to jurisdiction [...] the "equality of arms"; the nature of res judicata under Article 59 of the Statute; the role of the ad hoc or national judge; the effect of travaux préparatoires in the interpretation of the Statute of the Court; the role of and powers of chambers of the Court; the nature and effect of the Rules of Court; the relationship between jurisdictional and substantive parts of the proceedings; and the sufficiency of the Court's practice concerning confidentiality of written proceedings... it could be used by an imaginative law professor as the outline and textbook for a general seminar on international procedure, so important and farreaching are many aspects of this subject”, R. Bilder, Book Reviews and Notes: Intervention in the International Court of Justice, 89 AJIL (1995), 650 (emphasis added). 
This alternative and experimental narrative uses a tentative taxonomy of the different types of interaction between substance and procedure. ${ }^{27}$ The first interaction, examined through the prism of the goals of intervention, is procedure as house-keeping meaning that procedure serves to protect foundational and structural rights and general principles of procedural law, which are however, trans-substantive. By trans-substantive, we mean that regardless of the subject matter of the procedure, or the rights claimed, there are some default procedural rules that the Court must apply. These are essentially, the equality of arms and the good administration of justice. $^{28}$

The second interaction is procedure as transmission of substance meaning how procedure could or could not influence the application of substantive rights and how changes either in the procedural or in the substantive law affect one-another.

\section{A. Intervention in the ICJ - Procedure as House-Keeping}

The history of this procedural device and how it made its way into the Statute of the Permanent Court of International Justice can help show how

27 The categories are inspired from: J. S. Martinez, Process and Substance in the "War on Terror", 108 Columbia Law Review (2008), 1013. Martinez identifies five categories that are applicable in US "war on terror cases": "process as avoidance", where courts use process to avoid answering substantive questions; "process as signaling", where the court uses procedure to signal a substantive issue without settling it; "process as substance", when the court's choice of the applicable procedure is made with explicit reference to substantive rights; "substance disguised as process", when substantive questions are settled under the guise of application of procedural rules; and finally "procedure as housekeeping" where procedure is used to express more general values like the efficiency of adjudication.

28 Naming these two principles as "structural and constitutional general principles of procedure”, see R. Kolb, General Principles of Procedural Law, in A. Zimmermann et al. (eds.), The Statute of the International Court of Justice: A Commentary, $2^{\text {nd }}$ ed. (2012), 48, 871, paras. 9-28. It is very important to note however that herein these concepts or general principles are not used as referring to sources of international law. Rather, we conceive them as scientific generalizations flowing from the Rules of Procedure and the Statute of the Court; as underpinnings of the positive rules (for a similar argument, see J. Kammerhoffer and A. de Hoogh, All Things to All People? The International Court of Justice and its Commentators, 18 EJIL (2007), 971, 979. 
intervention fulfils the purposes for which it was established and how that leads to different modes of interaction with substance. ${ }^{29}$

The first attempt at codification of this practice is found in article 16 of the 1875 IDI Project:

Ni les parties, ni les arbitres ne peuvent d'office mettre en cause d'autres Etats ou des tierces personnes quelconques, sauf autorisation spéciale exprimée dans le compromis et consentement préalable du tiers.

L'intervention spontanée d'un tiers n'est admissible qu'avec le consentement des parties qui ont conclu le compromis. ${ }^{30}$ (Original in French)

The wording of this article of the Project and the order of its paragraphs makes clear that the main objective was to not prejudice third party rights without their consent. Intervention seems to have been added as the opposite side of the coin, protecting in turn the parties to the dispute from an intervention to which they have not consented.

The underlying rationale of the formulation of this article seems to be that decisions would be res inter alios acta for third parties, while parties to the dispute enjoy full autonomy and their consent is necessary for any potential 'intrusion. It has to be noted here that there was no qualification regarding the nature of the rights or interests which could constitute a valid ground for intervention.

The institution of intervention was addressed in more specific and narrow terms in The Hague Conventions Pacific Settlement of International Disputes of 1899 and $1907^{31}$ in Articles $56^{32}$ and 84 respectively. The latest formulation of 1907 which is, in substance, the same as the previous one, is:

The Award is not binding except on the parties in dispute.

29 This analysis is cursory and functional, aiming to lay the groundwork for an understanding of how intervention was introduced. However, the drafting history of intervention abounds with complexities, so a disclaimer is applicable in that this is a rudimentary, but hopefully sufficient account of the evolution of this procedural device.

30 Projet de règlement pour la procédure arbitrale internationale, supra note 2.

31 Convention for the Pacific Settlement of International Disputes, supra note 3.

32 For a detailed analysis of the introduction and underlying rationale of this Article in 1899, proposed by the Dutch Representative to the Peace Conference, T.M.C Asser, see S. Rosenne, Intervention in the International Court of Justice (1993), 14-18 [Rosenne, Intervention]. 
When it concerns the interpretation of a Convention to which Powers other than those in dispute are parties, they shall inform all the Signatory Powers in good time. Each of these Powers is entitled to intervene in the case. If one or more avail themselves of this right, the interpretation contained in the Award is equally binding on them.

In these conventions, intervention could be viewed as being added again as an exception, this time relating to the effect of the judgment.

The first paragraph of Article 84 embodied the general rule concerning the limited nature of res judicata, as relevant only between the parties. In this context, intervention was not only possible, but a matter of right. This right however applied only in the very specific cases where the dispute concerned the interpretation of a convention to which the third State to the dispute was also a party. Thus, if a State Party to a convention in question chose to exercise this right, then the strict relativity of the binding nature of the judgment would be amplified, since the part of the decision turning on the interpretation of the convention will be equally binding upon it.

Two conclusions can be drawn from the above: firstly, that intervention through implicitly recognising the existence of third party interests was only conceptualized as an exceptional means of protecting non-parties against prejudicial effect and of safeguarding party autonomy; secondly, the only goal that was thought of as necessitating protection was the readily identifiable interest a State had in the interpretation of a convention to which it was a party. ${ }^{33}$

We come now to the Statute of the Permanent Court of International Justice, prepared by the Advisory Committee of Jurists, established by the Council of the League of Nations based on the function entrusted to it under Article 14 of the Covenant of the League of Nations. ${ }^{34}$ The Advisory Committee kept intervention as of right in relation to multilateral treaties with little discussion and virtually no disagreement. ${ }^{35}$

33 These conclusions derive from the grammatical meaning of the Articles. The travaux do not shed light as to the actual intentions of their drafters, and as to the intended results of intervention, as Rosenne notes "[i]t is clear from the record that little if any thought was given by the participants in the Conference to the implications of introducing the concept of third-party intervention into interState arbitral proceedings, even in the limited form accepted by the Conference., ibid., 18.

34 Covenant of the League of Nations, 28 June 1919, 108 LNTS 188.

35 It was acknowledged by the Advisory Committee that this mode of intervention "was borrowed from Mr. Asser and based on Article 84 of the Convention of 1907” Permanent Court of International Justice, Advisory Committee of Jurists, 
The text of Article 63, unsurprisingly not deviating from the previous discussions, reads:

1. Whenever the construction of a convention to which states other than those concerned in the case are parties is in question, the Registrar shall notify all such states forthwith.

2. Every state so notified has the right to intervene in the proceedings; but if it uses this right, the construction given by the judgment will be equally binding upon it.

However, another form of intervention was added to the Statute. This form of intervention had no known precedent in international arbitration, ${ }^{36}$ and was largely based on the proposal by the Five Neutral Powers (Denmark, Netherlands Norway, Sweden, and Switzerland). ${ }^{37}$

Having no international antecedents, ${ }^{38}$ the motivation behind the adoption of this article could be traced in the discussions of the Advisory Committee, where it was felt that intervention would be "useless if this right were not conceded to wider extent". ${ }^{39}$ But the discussions do not shed adequate, if any, light on the specificities of intervention, namely, inter alia, for what purposes it would be permissible, what the requirements are and which procedural rights follow for the intervener.

Summing up the debate, Lord Phillimore proposed that a third State could request to intervene "if it consider[ed] that a dispute submitted to the Court affect[ed] its interests". While agreeing in principle, Mr. Fernandes, wanted the right of intervention to be subject to some condition, for example that it should concern "legitimate interests". The President of the Committee, Baron Descamps, proposed that a State could request intervention if it "consider[ed] that its rights may be affected by a dispute". To that, Mr. Adatci proposed changing the word "rights" to "interests", without however any documented exchange of views on the issue, or any rea-

Procès-verbaux of the proceedings of the Committee June 16th-July 24th 1920 (1929), 594 [Procès Verbaux].

36 Rosenne, Intervention, supra note 32, 20.

37 C. Chinkin, Article 62, in A. Zimmermann et al. (eds.), The Statute of the International Court of Justice, supra note 28, 1529, 1531 para. 3.

38 The broader notion of intervention was of course known to the members of the Advisory Committee through their national systems. The British member, Lord Phillimore and the Dutch M. Loder also brought examples of their domestic system's intervention procedures (Procès Verbaux, supra note 35, 592).

39 Procès Verbaux, supra note 35, 587, comment by Lord Phillimore 587. 
soning. ${ }^{40}$ Synthesizing the above views, President Descamps proposed the following wording that introduced a new form of discretionary and general intervention:

Should a State consider that it has an interest of a legal nature which may be affected by the decision in the case, it may submit a request to the Court to be permitted to intervene. It will be for the Court to decide upon this request. ${ }^{41}$

The articles were upheld with no substantive changes, ${ }^{42}$ making their way into the ICJ Statute.

Thus, the more general form of intervention encapsulated in Article 62 was loosely inspired by the domestic systems of the members of the Advisory Committee and followed as a logical counterpart of the more specific and narrow right of intervention, embodied in Article 63. However, the precise substantive underpinnings of Article 62 were left to be judged in practice, leaving a wide window open for substance to interact with procedure, since the general and abstract terms provided "a blank cheque" to the judges. ${ }^{43}$

Despite the relative opacity of the underlying reasons which led to the adoption of the articles on intervention, their inclusion inspired hope for the beginning of a new era in international dispute settlement, different from the ad hoc nature of international arbitration.

In an, in hindsight, idealistic tone John Basset Moore noted:

Perhaps it may be hoped that the right of intervention given by the Statute may prove to be a means of inducing governments, be they great or small, to come before the Court, thus showing their confi-

40 Ibid., 593; Rosenne aptly noted that the record of the discussion on the issue is "inconclusive and apparently garbled", Rosenne, Intervention, supra note 32, 23.

41 Procès Verbaux, supra note 35, 594. Note however, that this is the text of the Procés Verbaux. In the English language version of the PCIJ Statute, the phrase "as a third party" was inserted after "to intervene" in the first sentence. This phrase was however not maintained in the ICJ Statute, and this change was not considered as changing the substance of the article, see Documents of the United Nations Conference on International Organization, San Francisco, (1945), Vol. XIV, 676 UNCIO.

42 Ibid., UNCIO.

$43 \mathrm{H}$. Thirlway, The Law and Procedure of the International Court of Justice 1960-1989, Part Thirteen, 74 British Yearbook of International Law (2003), 23, 31. 
dence in it and enlarging its opportunities to perform a service for the world. ${ }^{44}$

Despite those hopes, the practice has been meagre. In the PCIJ, only one intervention was made by Poland in the Wimbledon case under Article $63 .{ }^{45}$ In the ICJ there have been 9 cases where requests were made under Article 62 of which only 3 have been granted. ${ }^{46}$ Under Article 63 there have been 4 declarations of which two were found admissible.

Thus, with the role and procedural effects of intervention unclear in the minds of drafters, and with a text having ambiguities and a traditional bi-

44 J. B. Moore, The Organization of the Permanent Court of International Justice, 22 Columbia Law Review (1922), 497, 507.

45 SS 'Wimbledon' (United Kingdom and ors v. Germany), Judgment, PCIJ Series A No 1, Judgment of 28 June 1923 (initially submitted as a request under Article 62).

46 The rejected requests to intervene were the following: Nuclear Tests (Australia v. France), Application to Intervene, Order of 12 July 1973, ICJ Reports 1973, 320; Nuclear Tests Application to Intervene, Order of 12 July 1973, ICJ Reports 1973, 324 , in which orders it was decided that the permission to intervene should be addressed in the decision of jurisdiction of the Court and Nuclear Tests (Australia v. France), Application to Intervene, Order of 20 December 1974, ICJ Reports 1974, 530; Nuclear Tests (New Zealand v. France), Application to Intervene, Order of 20 December 1974, ICJ Reports 1974, 535, where after finding the cases moot, the need to address questions on intervention ceased to exist; Continental Shelf (Tunisia/Libyan Arab Jamahiriya), Application to Intervene, Judgment, ICJ Reports 1981, 3, where Malta's legal interest was found not to be in conformity with the objectives of Article 62 in that it was an interest in legal principles and rules and their development, not specific enough to justify intervention; Continental Shelf (Libyan Arab Jamahiriya/Malta), Application to Intervene, ICJ Reports 1984,3 , where Italy's intervention was found to assert its rights vis-à-vis the parties to the dispute, which would not be compatible with the purposes of intervention, as it would in fact introduce a new dispute between her and the parties; Request for an Examination of the Situation in Accordance with Paragraph 63 of the Court's Judgment of 20 December 1974 in the Nuclear Tests (New Zealand v. France) Case, ICJ Reports 1995, 288, where the main case being removed from the General List, the requests by Samoa, Solomon Islands, the Marshall Islands and the Federated States of Micronesia became moot (these states also filed interventions under Article 63); Sovereignty over Pulau Ligitan and Pulau Sipadan (Indonesia v. Malaysia), Application for Permission to Intervene, Judgment, ICJ Reports 2001, 575, where the interest of Philippines was found to be too remote from the object of the case, in essence trying to forestall the interpretations of the Court; Territorial and Maritime Dispute (Nicaragua v. Colombia), Application for Permission to Intervene, Judgment, ICJ Reports 2011, 348, 420, where Costa Rica and Honduras respectively failed to show that they had an interest of legal nature 
lateralism outlook, the ICJ veered towards securing the classical housekeeping ${ }^{47}$ values in the first cases regarding intervention. ${ }^{48}$

In this vein, the limited recourse to intervention that came as a mismatch to the initial hopes for its potential importance can be explained through the house-keeping values applicable to all proceedings before the ICJ.

It is more logical than it is novel to argue that courts will uphold the constitutional and structural rules and principles of the system of which they form part. These foundational underpinnings will necessarily be embedded in all rules guiding their proceedings. In the international plane where state sovereignty and state equality leading to the principle of state

that might be affected. On the other hand, the cases admitted were the following: Land, Island and Maritime Frontier Dispute (El Salvador/Honduras), Application to Intervene, Judgment, ICJ Reports 1990, 92, where Nicaragua proved its interest of a legal nature since it was along with the main parties one of the riparian States in the Gulf of Fonseca where it was admitted by the parties that there was a "community of interests"; Land and Maritime Boundary between Cameroon and Nigeria, Application to Intervene, Order of 21 October 1999, ICJ Reports 1999, 1029, where the goal of protecting and informing the Court of its legal interests in the Gulf of Guinea was deemed in accordance with the requirements of discretionary intervention; Jurisdictional Immunities of the State (Germany v. Italy), Application for Permission to Intervene, Order of 4 July 2011, ICJ Reports 2011, 494 where the request of Greece was accepted on the grounds that the Court might find it necessary to consider its domestic decisions that were enforced (exequatur) by Italian courts and which were at issue between the parties.

47 The two inadmissible cases were Military and Paramilitary Activities in and against Nicaragua (Nicaragua v. United States of America), Declaration of Intervention, Order of 4 October 1984, ICJ Reports 1984, 215, where the request of El Salvador was deemed inadmissible since it related to the merits and not to the jurisdictional phase of the dispute, and the moot interventions by Australia, Samoa, Solomon Islands, the Marshall Islands and the Federated States of Micronesia in the Request for an Examination, supra note 46. The two admissible requests were: Cuba's intervention in Haya de la Torre Case, Judgment of 13 June 1951, ICJ Reports 1951, which was found admissible since and to the extent that it concerned the construction of the Havana Convention to which it was a party; New Zealand's intervention in the Whaling in the Antarctic (Australia v. Japan), Declaration of Intervention of New Zealand, Order of 6 February 2013, ICJ Reports 2013, 3, relating to the International Convention for the Regulation of Whaling.

48 Kolb, supra note 28, 698, (arguing that the Court emphasized the privacy of the parties and good administration of justice, in the sense of avoiding delays in the process instead of choosing to play a broader role ratione personae solving disputes.). 
consent to jurisdiction are still cardinal, ${ }^{49}$ procedure and its interpretation will necessarily mirror and uphold these values.

From these cardinal principles flows the procedural equality ${ }^{50}$ which is inherent in all judicial proceedings and has to be upheld in all cases. The difference between ad hoc / arbitral dispute settlement and the permanent jurisdictions is in the larger goal that the permanent jurisdictions have to play, that is, in the good administration of justice. The aim of each institution is different, with non-institutionalised arbitration serving the parties, and the ICJ serving the community of the States. ${ }^{51}$ And this is where the tension arises. Equality and classical house-keeping principles can collide with the necessary awareness of the systemic effects of a judgment and of multiparty interests at play within most disputes. ${ }^{52}$ Intervention stands at the crossroads of these two opposing tendencies and underlying values.

One characteristic example of the shift in stance of the Court comes with the recognition of the role of State consent to discretionary intervention under Article 62. Intervention, being an incidental procedure of which the Court is master and which is not directly dependent on the will of the parties, ${ }^{53}$ can be seen as a challenge to the procedural house-keeping

49 For a different view than ours, see A. Cançado Trindade, International law for humankind: towards a new jus gentium (I): general course on public international law, 316 Collected Courses of the Hague Academy of International Law (2005), 91, arguing that principles are not dependent on the consent of the subjects of law; see also Alleged Violations of Sovereign Rights and Maritime Spaces in the Caribbean Sea (Nicaragua v. Colombia), Preliminary Objections, Judgment of 17 March 2016 (unreported), Separate Opinion of Judge Cançado Trindade "state consent... is at most a rule (embodying a prerogative or concession to States) to be observed as the initial act of undertaking an international obligation", para. 27.

50 For procedural equality as stemming from the structure of the international legal system as opposed to the foundational principles stemming from national jurisdictions (specifically its counterpart audiatur et altera pars), see Mani, supra note $8,20$.

51 See also Kolb, supra note 28 , "[T] he ad hoc arbitrator exclusively pursues a utilitas singulorum of the parties electing him as their agent, whereas the ICJ also, and sometimes mainly, pursues a utilitas publica pertaining to the whole community of parties to the Statute., 876, para. 7.

52 See on this point S. Forlati, The International Court of Justice: an arbitral tribunal or a judicial body? (2014), 11 (more generally), 13, 173-186 (on intervention).

53 On the compulsory nature of incidental procedures, see H. W. Briggs, The Incidental Jurisdiction of the International Court of Justice as Compulsory Jurisdiction, in F. A. von der Heydte et al. (eds.), Völkerrecht und rechtliches Weltbild (Festschrift für Alfred Verdross) (1960), 87, 93-94; on intervention in particular, see: 
principles of state consent, equality of parties and protection of their autonomy, as well as a delay of the proceedings. ${ }^{54}$

However, the above interpretation given to incidental proceedings as being compulsory, flowing directly from their nature as incidental proceedings was not readily embraced. ${ }^{55}$ This seems to have changed, along with a more restrictive approach regarding the object of intervention with the first decision where Article 62 intervention was allowed. In the Land, island and maritime frontier dispute the Court rejected the necessity of jurisdictional link when the intervener was not seeking to become a party to the case,

"If it were necessary to find a consensual element in such proceedings, it could be found in the fact that by becoming a party to the Statute of the Court a State accepts the institutional or incidental jurisdiction conferred on the Court by that Statute in cases in which the Court has been seized of a dispute involving that State. Even, where the Court's original title to jurisdiction over the merits rests on terms of a special agreement [...] the proceedings can take on the characteristics of compulsory jurisdiction where the Court finds it necessary to invoke its incidental jurisdiction in relation to matters falling outside the scope of the special agreement".

54 The related Rules of the Court (Articles 81-86) are very instructive if seen from the house-keeping perspective. For example, the filing of the request of intervention 'as soon as possible or and not later than the closure of the written proceedings', (Article 81(1)) for the request under Article 62 and a slightly laxer limit for Article 63 , namely 'as soon as possible, and not later than the date fixed for the opening of the oral proceedings' (Article 82(1)), show that there is care not to delay the procedure whereas the time-limits are different for intervention as of right and for discretionary intervention. Additionally, another facet of the house-keeping interface can be detected in relation to the modalities of written comments submission by the interveners on the pleadings of the parties. While in the case of intervention under Article 62, a further time-limit is fixed for parties to respond, if they so wish, to the written observations of the intervener (Article 85), in the case of intervention under Article 63, this option is not given to the parties (Article 86). This further highlights how in discretionary intervention, where the interest is not presumed, the parties are structurally allowed to play a more active role in safeguarding their autonomy.

55 In fact, interestingly enough this issue was regurgitated by the 1978 amendment of the Rules of the Court. As the then Vice President Sette-Camara in his Dissenting Opinion in the Continental Shelf case (Tunisia/Libyan Arab Jamahiriya), supra note 46 , remarked "[w]e see that the more than 60 years of controversy on the problem of whether the intervening State has, or has not, to prove the existence of a jurisdictional link with the principal parties, was resurrected by the revision of the Rule" para 29, emphasis added. 
arguing that intervening and introducing a new case as a party is a "difference in kind" 56

The case law on intervention can be seen from this perspective as a gradual shift of the Court from over-emphasizing the will of the parties, reciprocity, equality and party autonomy embedded in its rules, to then becoming laxer with its approach and trying to strike a better balance between house-keeping of traditional values ${ }^{57}$ and stepping timidly towards a broader perspective of its role. ${ }^{58}$ However, inconsistencies remain, and further case law is needed to test the position of the Court.

\section{B. Procedure as Transmission of Substance - The Case of the 'Legal Interest'}

As discussed, despite the general framework of permissible motivations of intervention and their procedural effects not being predefined in their entirety, what is certain is that States attempting to intervene must establish a connection with the main case. This connection, and the admissible motivations, uncovers the transmission of what is herein defined as substance through procedure. In Article 63 this connection is explicitly provided, since being party to a Convention the construction of which is in question

56 Land, Island and Maritime Frontier Dispute (El Salvador/Honduras), supra note 46, para 97.

57 It seems that especially in relation to maritime delimitations, which would appear to be within the scope of intervention, the Court has followed a very strict approach, arguing for a very high threshold of proof of the interest that might be affected. The Court stressed that in its settled jurisprudence regarding delimitation, it takes care not to prejudice or decide on third party rights. The latter will remain protected by Article 59 of the Statute. See the latest decisions on the issue, Territorial and Maritime Dispute (Nicaragua v. Colombia), supra note 46, in particular Application by Costa Rica for Permission to Intervene, paras. 87-89. For a criticism of this approach, see B. Bonafé, Interests of a Legal Nature Justifying Intervention Before the ICJ, 25 LJIL (2012), 739, 745-750.

58 In this regard, Judge Cançado Trindade notices a change in the role of the Court, after allowing intervention in the Jurisdictional Immunities case, supra note 46, and the Whaling in the Antarctic case, supra note 47. In his Separate Opinion in the latter case he argues that the institution of intervention has been "resurrected" in a "revitalized way" in that in both cases wider issues and interests of third parties were at stake, so the Court assumed a more important role under Article 92 of the United Nations Charter (paras. 66-67). What does not seem to have been taken into account however is, that in both cases neither party formally objected to intervention. So we respectfully submit that optimistic conclusions remain tentative. 
in the main case, suffices to create a right to intervene. In the case of Article 62 , however, the ground on which the potential interveners might be permitted to intervene is the "interest of a legal nature" that might be affected by the main case. However, both modes of intervention are based on the existence of an interest. ${ }^{59}$ The difference between them is that in the case of Article 63, the interest is less general, easily identifiable and, in essence, automatically acknowledged.

Viewed from the perspective of transmission of substance through procedure, it is telling that Article 63 is the oldest conceived form of intervention, and second that it is couched in terms of rights. These choices can be instructive in that they demonstrate which substantive rights are transmitted through this article, and are thus deemed sufficient to intrude in the bilateralism of the case.

Arguably, drawing from the principle of State sovereignty and equality, States that are Parties to a Convention should be able to be heard in cases concerning its interpretation; their interests in the interpretation of the treaty are equal to those of all State parties to the treaty.

This, however, entails two further assumptions. First, that the relativity of res judicata is not enough to protect State Parties to a Convention from an interpretation of the Court that would be considered authoritative; and second, that there is value in the coherent interpretation of treaty rules and in the avoidance of repetitive litigation. ${ }^{60}$

The question then again turns on the substantive third party interests that can find their way into the consideration of the Court via the device of intervention. If the above assumptions concerning Article 63 are correct, then there has to be a difference in the nature of the interests affected by the interpretation of a treaty rule and that of another rule not embodied in a treaty, which might be interpreted by the decision and affect the intervener.

59 See Rosenne, Intervention, supra note 32, 72-23, arguing that the reason of the "virtually complete unification" of the Rules of Procedure regarding both modes of interventions, flows exactly from the commonality of the basis of both interventions, jurisprudential differences aside. Rosenne posits that, as hinted in the travaux of the PCIJ Rules of Procedure, "intervention under Article 63 is a form of intervention to protect an interest of a legal nature, not which may be affected by the decision in the case but in the more limited sense that it may be affected by the interpretation given by the Court to the multilateral treaty in question".

60 C. Chinkin, Article 63, in Zimmerman et al. (eds.), The Statute of the International Court of Justice, supra note 28,1573, 1575 para. 4 (arguing that this is the underlying rationale of the article). 
As aptly put by Judge Oda:

If an interpretation of a convention given by the Court is necessarily of concern to a State which is a party to that instrument, though not a party to the case, there seems to be no convincing reason why the Court's interpretation of the principles and rules of international law should be of less concern to a State... therefore, ... it may be asked why the interpretation of the principles and rules of international law should exclude a third State from intervening in a case. ${ }^{61}$

The difference between the two modes of intervention is that the generally formulated interest poses a challenge to the system, potentially opening up the bilateral dispute to "more diffused and less tangible third party legal interests". ${ }^{62}$ Thus, the interpretation of interests of a legal nature offers an entry point to the evolution of substantive rights that can be protected through intervention. On that level, the definitions of interests and the progressive development of substantive law which relates to the interpretation of interests of a legal nature ${ }^{63}$ becomes a direct connector between substance and procedure.

On a second level however, there are inherent limits where intervention as an incidental procedure cannot be affected by changes in the substantive law. In these cases, if a mismatch of the evolution of the substantive interests and the functions of the procedure is created, then interpretation can reach its limits and the procedure might have to be changed to accommodate qualitative changes in interests.

The interest of a legal nature has long been discussed as being very difficult to define, ${ }^{64}$ particularly due to the marriage of two words that did not, at least when coined, correspond to any terminus technicus. ${ }^{65} \mathrm{~A}$ consistent thread of what is a legal interest begins to appear through the decided cas-

61 Continental Shelf (Libyan Arab Jamahiriya/Malta), supra note 46, Dissenting Opinion of Judge Oda, para. 15.

62 Kolb, supra note 28, 696.

63 See also supra note 58 and the accompanying text.

64 Focusing specifically on the interest of a legal nature, see E. Doussis, Intérêt juridique et intervention devant la Cour internationale de justice (2001), 105 RGDIP, 55; S. Forlati, 'Interesse di natura giuridica' ed effetti per gli stati terzi delle sentenze della Corte internazionale di giustizia, 85 Rivista di diritto internazionale (2002), 99; Bonafé, supra note 57; Wolfrum, supra note 15.

65 It is noteworthy that the first authors writing on the intervention before the PCIJ characterised the interest of a legal nature as a "monstre presque indéfinissable", W. M. Farag, L'intervention devant la Cour permanente de Justice internationale (articles 62 et 63 du Statut de la Cour) (1927), 59, while Bastid notes "on sait ce 
es, despite the fact that the judges have to interpret this requirement on an ad hoc basis.

One way to examine the connection between the definitions in substantive law and their interaction with the procedure is to approach the definition of the term 'interest of a legal nature' in relation to two other contiguous concepts. The first is whether interests of a legal nature are different than rights. The second is whether legal interests in the sense of Article 62 are influenced by the progressively changing requirements of standing before the Court. Both approaches serve to show how interpretation of substance limits or broadens the ambit of permissible intervention.

In the first approach, if legal interests are equated with rights, ${ }^{66}$ then the requirement of showing a legal interest would be clearer in terms of what the intervener should prove. But, rights, when defined as entitlements flowing from positive international law, are more narrow and specific than interests. So, the interpretative equation of rights with interests of legal nature would have as a result to limit the acceptable ambit of intervention and would require a greater burden of proof on the part of the intervener. ${ }^{67}$ In this case, a two-part approach was used, based on the nature of the interest on the one hand, and on the connection with the main case, on the other. First that the interest should be real, concrete and based on law, as

qu'est un droit, on sait ce qu'est un intérêt, mais on ne sait pas ce que peut être un intérêt-droit ou un droit-intérêt”, P. Bastid, L'intervention devant les juridictions internationales, 36 Revue politique et parlementaire (1929), 100, 103.

66 Defending this minority opinion, see Dissenting Opinion of Judge Ago, Continental Shelf (Libyan Arab Jamahiriya/Malta), supra note 46, 124, para 16 ("an interest of a legal nature being nothing other than a right”); Declarations of Judges Al-Khasawneh, Territorial and Maritime Dispute (Nicaragua v. Colombia), Application by Costa Rica for Permission to Intervene, supra note 46 (paras. 18-29); Ibid., Declaration of Judge Keith, devoting the entirety of his opinion to examine the differences between rights and interests of a legal nature and all the related case law, concluding that the concepts are in practice used interchangeably, so that even if there is a difference in the meaning of terms, the distinction is not useful. In the same case, cf. Dissenting Opinion of Judge Abraham "It is well known and well recognized, both in doctrine and in jurisprudence, that an "interest" should not be confused with a "right"; while it is not always easy to define the dividing line between the two categories, it is certainly not permissible to confuse them" para. 6. See also Kolb, supra note 28 , 706-707, who argues that the difference is well known in municipal law, but that international law has not yet reached a point where it can differentiate between these legal facets.

67 The Court supported this view in the first case where it defined the interest of a legal nature Territorial and Maritime Dispute (Nicaragua v. Colombia), Application by Honduras for Permission to Intervene supra note 43, para 26. 
opposed to interests of another nature, such as political, economic or strategic. Second that it should be potentially affected by the decision. ${ }^{68}$

More generally, it seems that a permissible interest of a legal nature for the purposes of intervention has slowly started to consolidate and could be defined as part of a more general spectrum of rights and interests related to the Court's mainline and incidental jurisdiction. ${ }^{69}$ On one end of the spectrum stand the rights which form the very essence of the case. Without the participation of the States whose rights form the very subject matter of the case, the case cannot continue even with the consent of other states that also have claims related to the dispute. ${ }^{70}$ On the other end stand either general, non-individuated ${ }^{71}$ legal interests, ${ }^{72}$ or interests which are not connected to the dispute. ${ }^{73}$

Going back to the evolution of interests based on law, and the impact they can have on procedure, Judge Weeramantry's Opinion in the Pulau Li-

68 Ibid. (emphasis added).

69 See Bonafé, supra note 57. This author identified four types of interests which justify intervention: Interests that are the very subject matter of the decision, directly affected interests, interests affected by implication and generalized interests. It is worth noting that the category of interests affected by implication relates only to the interests claimed by Greece in its intervention in the Jurisdictional Immunities case, supra note 43 . This being the latest decision of the Court on a request for intervention, it can be seen as a further loosening of the criteria of legal interest. On the other hand, in accordance with the above identified house-keeping goals the fact that none of the parties formally objected to the intervention, should be taken into account.

70 The principle, that where a third party is indispensable the dispute cannot be adjudicated without its presence, was established in the Monetary Gold Removed from Rome in 1943 (Italy v. France, United Kingdom of Great Britain and Northern Ireland and United States of America), Preliminary Question, Judgment, ICJ Reports 1954, 19. The principle was applied again in the case of East Timor (Portugal v. Australia), Judgment, ICJ Reports 1995, 90, (see in particular paras. 28, $35)$.

71 The interest should be "personnel et concret" and not "impersonnel et théorique", K. Mbaye, L'intérêt pour agir devant la Cour Internationale de Justice, 209 Collected Courses of the Hague Academy of International Law (1988/II), 223, 292.

72 Continental Shelf (Tunisia/Libyan Arab Jamahiriya), supra note 46, para. 19 (" $[t]$ he interest of a legal nature invoked by Malta does not relate to any legal interest of its own directly in issue as between Tunisia and Libya in the present proceedings $[\ldots]$ [i] t concerns rather the potential implications of reasons"); Island and Maritime Frontier Dispute (El Salvador/Honduras), supra note 46, para. 76, where the Court explicitly ruled out interests "in the general legal rules and principles likely to be applied by the decision".

73 Sovereignty over Pulau Ligitan and Pulau Sipadan, supra note 1, para. 82. 
tigan and Pulua Sipadan case ${ }^{74}$ is very relevant in this regard, and his approach merits citing at length:

It enhances the importance of this subject to note that although it may on first impression appear to relate to a merely procedural and incidental matter, it is closely intertwined with substantive law and its development. This was well illustrated in the first case to come before the Court under Article 62, the case of Fiji's attempted intervention in the case between Australia and France relating to nuclear testing. Doubts were expressed at that time on the question whether atmospheric damage through nuclear testing constituted an interest of a legal nature. International environmental law has progressed so far since then as to render incontestable that this is an interest of a legal nature, thus effecting a change in procedural consequences through a change in substantive law.

This observation clearly raises the question of obligations erga omnes..$^{75}$ The shift in defining what is a legal interest stems from the famous obiter dictum in the Barcelona Traction case, where it was recognized for the first time that there are obligations which, due to their importance, are owed "to the international community as a whole" and thus "all States can be held to have a legal interest in their protection" ${ }^{76}$ This is in turn related to recognition of secondary norms of State responsibility to protect these interests. ${ }^{77}$

74 Ibid., Separate Opinion of Judge Weeramantry, para. 11.

75 It should be noted that collective interests stemming from a Convention, creating obligations erga omnes partes, are clearly within the ambit of intervention under Article 63, which does not differentiate between the nature of obligations created by treaties. This is exemplified in the Whaling case, supra note 47 , where despite New Zealand's claims that the "[c]ontracting governments have a collective interest" in the performance of rights established by the Whaling Convention, the Order of the Court did not mention the nature of the rights established under the treaty (Declaration of Intervention of New Zealand, para. 23 available at http://w ww.icj-cij.org/docket/files/148/17256.pdf, last visited 10 August 2017). Thus, in this respect, a clear distinction should be drawn between the importance of interests erga omnes partes for reasons of intervention and for reasons of admissibility as in the case of Questions relating to the Obligation to Prosecute or Extradite (Belgium v. Senegal), Judgment, ICJ Reports 2012, 422, para 68.

76 Barcelona Traction Light and Power Company Limited (Belgium v. Spain), Judgment, ICJ Reports 1970, 3, para 33.

77 See ILC, Commentary to the Articles on the Responsibility of States for Internationally Wrongful Acts (ASR), YbILC, 2001, A/CN.4/SER.A/2001/Add.1 (Part 2), 20, establishing that both specially affected and non-injured states have a legal interest and can invoke the breach of an obligation owed to the international 
However, changes in the primary and secondary norms do not automatically translate into changes in the interpretation of procedural norms. The requirements of invocation of responsibility, standing and admissibility of a claim are different in kind than those of intervention. ${ }^{78}$ Nonetheless, it would be paradoxical to claim that if the requirements for invocation of responsibility and standing are fulfilled then, the less stringent requirements under article 62 will not be,$^{79}$ and it has been argued that these interests are sufficient and not "improper" for the purposes of intervention. ${ }^{80}$ Moreover, as a matter of legal policy, a consistent interpretation of these different interests will be beneficial. ${ }^{81}$

A further question arises then, linking back to the house-keeping values identified above. When interpreting interests of a legal nature, we should consider whether generalised interests and interests owed to the international community as a whole, will be considered as an actio popularis through the backdoor of intervention ${ }^{82}$ or will water down the procedure of intervention, transforming it into a kind of amicus curiae participation, ${ }^{83}$ intruding upon party autonomy and thus potentially eroding the confidence of States in the Court.

In our opinion, the Court should strive to strike a balance between discouraging State consent to its jurisdiction and fulfilling its role in the ad-

community as a whole (see Article 42(b) 118-119, paras. 11-12 and Article 48(1) (b), 127, paras. 8-9).

78 Chinkin, supra note 25, 160.

79 G. Gaja, The Protection of General Interests in the International Community, 364 Collected Courses of the Hague Academy of International Law (2013), 119.

80 Arguing that obligations erga omnes can create interests of a legal nature in the sense of Article 62, see R. Bernhardt (Rapporteur), Report - Final Version. Judicial and Arbitral Settlement of International Disputes Involving More than Two States”, 68-I Annuaire de l'Institut de droit international (1999), 60,120; S. Forlati, Azioni dinanzi alla Corte internazionale di giustizia rispetto a violazioni di obblighi erga omnes, 84 Rivista di Diritto Internazionale (2001), 69,108; Bonafé supra note 57, 755-756 (but limiting it in the case of a specially affected third state, in the sense of Article 42 of the ASR).

81 Benzing, supra note $15,399$.

82 For the impermissibility of introducing an actio popularis through intervention, see E. Jimenez de Arechaga, Intervention under Article 62 of the Statute of the International Court of Justice, in R. Bernhardt et al. (eds.), Völkerrecht Als Rechtsordnung, Internationale Gerichtsbarkeit, Menschenrechte: Festschrift für Hermann Mosler (1983), 453, 461.

83 Suggesting the introduction of a new procedure for more generalised interests, see Chinkin, supra note 25, 286, 287; P. Palchetti, Opening the International Court of Justice to Third States: Intervention and Beyond, 6 Max Planck Yearbook of United Nations Law (2002), 139, 174-179. 
ministration of justice in the international community. But the latter cannot happen through either narrow or expansive interpretations of its procedural law. The permeability of the substance-procedure boundary has its limits. To facilitate and reflect changes in the substantive law, but also, and perhaps more importantly, to accommodate shifts towards systemic values, the text of Rules of the Court should be changed.

As put by Jenks half a century ago:

In every legal system law and procedure constantly react upon each other. Changes in the substantive law call for new procedures and remedies; new procedures and remedies make possible changes in the substantive law. So it is in international law; if we wish so to develop the law as to respond to the challenge of our times our procedures and remedies must be sufficiently varied and flexible for the purpose. We cannot be content to inherit; we must also create. ${ }^{84}$

\section{Conclusions}

The division between substance and procedure is one of the binaries which make sense both from a normative and an analytical perspective. Despite theoretical complexities, having a working definition, specific to a legal system or a Court, is not a matter of theoretical enquiry but of practical importance, as demonstrated above with the examples of local remedies rules and immunities. However, the categorization of norms will not be clear-cut and legal concepts will often straddle the line. The underpinnings of norms and institutions that stand behind the categories of substance and procedure, work in tandem to produce decisions.

In this contribution we tried to show how this interaction between fluid categories can help gain a different perspective of the application of law.

On the one hand, we have shown that the Court has to perform a housekeeping function, upholding the values of the system, good administration of justice and state consent. On the other, as the only international court with general jurisdiction, it should take into account the systemic effects of its judgments and try to transmit the changes in substantive law through a harmonious interpretation of its procedure, taking into consideration, at the same time, the inherent limits to intervention as an incidental procedure.

84 C. W. Jenks, The Prospects of International Adjudication (1964), 184 (emphasis added). 
To conclude, the dividing line between substance and procedure continues to carry explanatory force, uncovering important implicit assumptions which play out in the context of intervention before the ICJ as evinced in our analysis. The examination of third party intervention before the International Court of Justice showed how a procedure with uncertain goals in a bilateralist system can provide an entry point to the accommodation of third party interests as well as emerging community interests. However, to do so, the Court has to use intervention and its procedure in the manner of a balancing act. Moreover, whether it intends to accommodate such interests remains to be seen, as further case law is needed to reach more definite conclusions.

On a more general note, theoretical explorations and taxonomies of the interface between substantive and procedural rules can prove to be a very fertile ground for international legal research due to their potential to deepen our awareness of the connection between institutional design of procedures and underlying choices regarding substantive protection of rights. 
